\title{
STORAGE VESSELS IN THE LATE ROMAN AND EARLY MIGRATION PERIOD IN THE POLISH WEST CARPATHIANS
}

\author{
Economic Aspect
}

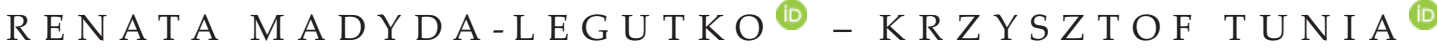

\begin{abstract}
The article concerns large storage vessels (Krausengefäße) from the Late Roman Period and the Early Migration Period, found in large numbers in the Polish West Carpathians. Traditionally, it has been assumed that they were used to store grain. It seems, however, that storage vessels found inside houses probably were local 'pantries' - places used to keep various agricultural and gathered produce and its products, intended for direct consumption. They were probably also used to store drinking water. Storage vessels dug into the ground outside houses may have served as local reservoirs of water for consumption or pottery manufacture. The water might have been brought to the settlement in other, smaller, 'storage' vessels. On the other hand, ground granaries and pits dug in the ground, properly secured against birds, rodents and postharvest pests, were much more suitable for long-term grain storage. The characteristic rim of the Krausengefäße vessels, shaped as a flange, was undoubtedly functional and connected to the vessel's closure system. It was an element of a tight cover whose function was to make access to the inside of the vessel as difficult as possible. The lid was probably made of organic material, thick textile of leather, which - once placed over the vessel and tied under the flange - tightly sealed the vessel. This flange-shaped rim was an important invention, which served to strengthen the edges of the vessel and allowed the vessel to be closed easily, quickly and tightly. It secured the contents during both transport and storage.
\end{abstract}

Keywords: Polish West Carpathians, Late Roman and Early Migration Periods, storage vessels.

Pottery is the most common bulk material found at the settlements from the Roman Period and the early phase of the Migration Period. In the literature, a lot of attention has been devoted to the typological and technological aspects of such finds, much less to their function; the latter is more difficult to analyse and requires historical and ethnological reflection and often also specialist analyses.

For the purposes of this article, the broad ceramic set of that time has been narrowed down to the large-capacity vessels known as Krausengefäße. They appeared in the area of Central European Barbaricum in the Late Roman Period and differed in the method of manufacture, shape and proportions depending on the region in which they were made. Their precursors were large storage vessels with a flange, known already in the Celtic world (Furger-Gunti 1979, 87; Woźniak 2000, 302).

Such vessels have garnered interest for quite some time. Works on the subject, based on the material from Silesia (Boege 1937; Jahn 1925; von Richthofen 1928) or analysing vessels from the former territory of Eastern Lesser Poland (Śmiszko 1939/1948), were published already in the first half of the $20^{\text {th }} \mathrm{c}$. The advancement of the research in the Przeworsk culture area resulted in further publications (Bohr 2008; Dobrzańska 1990, 46-48; Godłowski 1969, 99, 100, 174; Machajewski/Pietrzak 2008, 235-237; Marchelak 2010, 104, 113-115, 119, fig. 11: 1-4; Pazda 1980, 199-202; Rodzińska-Nowak 2006, 131-138; Wilk 2005; Żychliński 1999; 2008).

Vessels of the Krausengefäße type undoubtedly appeared to satisfy some economic needs of the then community. Not without significance is their similarity to the large storage vessels used in the Roman world. They correspond to two categories of Roman pottery, i.e. dolia (dolium) and amphorae (Peña 2011, 20). The former are very large vessels with a capacity of 400-3000 litres; they were permanently dug in the ground and generally used to store wine, olive oil, oil, grains. The latter vessels were smaller, with a capacity of 6-150 litres, and served as portable containers for transport and storage. They were used to distribute freshly made goods and post-distribute various products. They were mainly used for foodstuffs - wine, olive oil, oil, processed fish, fruit. However, their use was wider ranged; they served as a universal packaging for goods which are only partially recognised today. The literature and finds attest that amphorae 
were used to transport and store alum, tar, resin, honey, nuts, cabbage, etc. (Peña 2011, 25).

In the studies on the Roman Period in the Central European Barbaricum, much attention has already been devoted to the economy, but deliberations on the functional aspect of pottery are rare. The discussions have mainly focused on the potential uses of ceramics. In general, a distinction has been made between table- and kitchenware, while the function of large storage vessels has been considered less often, despite the fact that such vessels constitute a significant percentage share of the pottery assemblage of the communities of the period discussed, at least in the upper basins of the Vistula and the Oder Rivers, and especially in the mountain areas. The digging of large vessels into the ground within the settlements has been noted.

When attempting to determine the purpose of storage vessels in our area of interest, it is necessary to refer - for lack of direct information - to the data from the analysis of the material from the Imperium Romanum, where large vessels had economic use. However, the reconstruction of the whole variety of uses of pottery is made difficult by the issue of the primary use for which the vessel was manufactured and its secondary, often ad hoc, uses (e.g. a doghouse from a horizontally placed large vessel; a container for a liquid for poultry or a dog at a farm, made from a fragment of such a vessel; a large sherd used as a lid of a vessel, etc.; Peña 2011, 193-208). It is then worth focusing on the suggestions concerning only the most likely forms of primary use of large vessels in our area of interest.

In the Late Roman Period and the Early Migration Period in the Polish Carpathians, fragments of vessels with flange-shaped rims (Krausengefäße) and, in exceptional cases, also whole vessels of the same type can be found in large numbers at settlement sites. The share of storage vessels in the ceramic material varies between different settlements in the Beskid Mts zone. If we compare the number of sites from the Polish Carpathians dated from the Late Roman Period to the Early Migration Period and the similarly dated sites where vessels of the Krausengefäße type have been found, it can be observed that such specimens were present at almost half of all sites (Madyda-Legutko 1995, list III; V; map 4; 5; Wilk 2005, 342). As a result of new excavations, the share of storage vessels in the pottery assemblage is gradually increasing. Thus, they were common vessels, probably multifunctional, serving purposes which are difficult to unambiguously determine but most probably related mainly to the food economy.
The range of occurrence of storage vessels in the Carpathians is not limited to the Polish Carpathian zone only, as they are also known from the area south of the main Carpathian watershed - from Orava (Čaplovič 1987, 192, 193, fig. 88: 1, 4, 6-8; Lofajová Danielová/Furman 2019; Pieta 1991, fig. 5: 10), Spiš (Giertlová-Kučerová/Soják 2005, 122, fig. 8: 7, 8; 9: 1, 2; 10: 3, 4; 14: 2, 5, 6, 7; Pieta 2003, 156-158, fig. 6: 22, 24), Liptov (Pieta 1991, fig. 5: 11) and from the vicinity of the town of Prešov in eastern Slovakia (Lamiová-SchmiedloválTomášová 1999, 99, pl. III: 17; VI: 3-5; XI: 6). It can then be said that they are one of the many elements of the set of vessels used by the people of the so-called North Carpathian group. They are also found farther to the east, at the settlements of the Carpathian Barrow culture located in the foreland of the East Carpathians (Vakulenko 2010, 118, 119, fig. 64: 1-3; 65: 1-4). Numerous fragments of storage vessels also occur north of the Polish Carpathians, in the material from the settlements of the Przeworsk culture population, from almost the entire area that it occupied, and are particularly common in Lesser Poland and Silesia.

The storage vessels with flange-shaped rims known from the Polish Beskid Mts zone differ mainly in the technology of manufacture and in some morphological features. They were formed either from clays tempered with coarse- and medium-grained crushed stone or from clays with no or an insignificant amount of coarse-grained mineral temper and mainly with an admixture of sand or chamotte (Madyda-Legutko 1995, list V.1; V.2; map 6; 1996, 83-91; 2011, 298-300, 302). The first group is dominant in the western part of the Carpathians, the second in the San River basin (Madyda-Legutko 1996, 85; 2011, 297-300, fig. 2: 11; 4: 1a, b; Wilk 2005, 344). It should be noted here that, in terms of technology, vessels of the first group are characteristic of the pottery developing in the territory of the Przeworsk culture, i.e. in the areas located to the north of the Carpathians. On the other hand, the manufacture of storage vessels from clays without a significant amount of mineral temper is alien to the traditions of the Przeworsk pottery and is reminiscent of the pottery of the Dacian circle (Madyda-Legutko 1996, 90, 91; 2011, 298, 300).

In this article, we wish to focus on the storage vessels discovered in the West Carpathians, including the Sacz Basin, the Beskid Sądecki Mts and, to some extent, the adjacent mountainous areas of Slovakia, i.e. in an area of a certain cultural unity referred to as the North Carpathian group.

The storage vessels from the Polish West Carpathians differ in dimensions, proportions and 
shape of the rim. The vessels reach $80 \mathrm{~cm}$ in height, and the inner diameter of the rim is always smaller than the diameter of the body and the height of the vessel. In all probability, the height of the vessel was limited by the length of a hand with a scoop used to remove its contents. The vessels usually have bulbous bodies, with maximum circumference positioned above half the height of the vessel. Such features also characterise storage vessels from other parts of the Polish Carpathian zone. Slimmer specimens, with more egg-shaped bodies, are occasionally encountered. A few examples have distinct necks (Madyda-Legutko/Tunia 1993, pl. XXII: a).

A considerable variety is observed in the shape of the flange that crowned the vessels and after which they were named (Fig. 1: 21). The flange of the vessels from the Beskid Sacdecki Mts and the Sacz Basin is most often either expanded on both sides and rounded or sharply bevelled on the outside and inverted to various degrees (Madyda-Legutko 1996, 87, fig. 8: 1-3, 5, 6, 11-13; 9: 1-5, 8, 10-12; Madyda-Legutko/Tunia 1993, fig. 10-13). It usually measures $3-5 \mathrm{~cm}$ in width; the widest ones reach $6 \mathrm{~cm}$ (Madyda-Legutko/Tunia 1993, 58). In the areas farther to the east, on the upper San River, a greater diversity of rims can be observed (Madyda-Legutko 1996, 90, fig. 10: 7-9; Wilk 2005, fig. 4; 5). The flange, sometimes with circumferential grooves on the upper surface, was undoubtedly functional, not decorative and was most likely related to the vessel's closure system. It was an element connected to the lid, a tight cover, the purpose of which was to make access to the inside of the vessel as difficult as possible. The lid was probably made of organic material, thick fabric (felt) or leather, which - once placed over the vessel and tied with a cord under the flange - tightly sealed the vessel. According to some researchers, the lid may have been in the form of a flat disc made of wood (Dobrzańska 1990, 47; Wilk 2005, 365). However, even in such a case, the tightness of the closure was guaranteed by the additional cover of organic material tied under the flange. Therefore, this flange-shaped rim was an important invention, which served to strengthen the edges of the vessel and made it possible to close the vessel easily, quickly and tightly. It protected the contents during both transport and storage.

Storage vessels were mainly hand-made, although traces of use of a potter's wheel are also sometimes visible. During the field exploration of the storage vessel at Moszczenica Wyżna, Nowy Sącz district, site C, feature no. 1 (Fig. 1: 19, 20; Madyda-Legutko/Tunia 1978, 122, fig. 13), it was observed that it had been built from several-centimetre-wide bands. Traces of fusing the bands used to make the vessels are also visible on the sherds of storage pottery from the settlement at Lesko, Lesko district on the San River (Barłowska 1984, 65; Wilk 2005, 347). ${ }^{1}$ In some storage vessels, traces of use of a potter's wheel are observed not only under the rim but also on the parts near the bottom; for example, a circumferential ring on the base of one of the vessels from Rytro, Nowy Sacz district, site A (Madyda-Legutkol Tunia 1993, 60, 61, pl. XXII: a). ${ }^{2}$

The storage vessels from the West Carpathians, regardless of their size and manufacturing technique, are decorated mainly with incised ornamentation, placed in the upper part of the body. It takes the form of a single or multiplied wavy line, arranged in a single, double, sometimes triple band, even of a garland character (Barłowska 1984, pl. III: 1; Madyda-Legutko 1996, 89; Wilk 2005, 357, 361, fig. 9; 10). Ornaments in the form of parallel deep grooves also appear on the upper part of the body. The storage vessels from the Beskid Sacdecki Mts and the Sacz Basin were not decorated with stamped ornamentation, which was sometimes used to embellish the flange and bodies of the storage vessels from the settlements in the upper Poprad River basin (Giertlová-KučeroválSoják 2005, fig. 8: 7; 9: 1, 2; 14: 2, 3).

At the excavated settlements in Beskid Sądecki Mts, storage vessels were discovered mainly within large residential features. At the settlement at Moszczenica Wyżna, Nowy Sącz district, site C (437 m a.s.1.), a storage vessel, $80 \mathrm{~cm}$ high (Fig. 1: 19, 20), was dug into the ground near a house (feature no. 9) and farm buildings (Madyda-Legutko/Tunia 1978, 122, 123,

\footnotetext{
1 It is believed that Greek immense storage vessels (pitos, pithoi) were probably built in parts - after drying one part of the vessel, another one was added - as there was a risk that the lower walls may collapse under the weight of the upper parts. This has also been confirmed by the observations of contemporarily made copies of such vessels; they are made from 2-3 separate parts, which are fused together only at the end of the whole process (http://www.crete.pl/znaleziska-archeologiczne/pitos. html [21. 1. 2021]). Thus, the use of a potter's wheel to make such vessels required a lot of skill.

There was also a proverb in ancient Greece saying that making a pitos required a lot of experience and knowledge $-\alpha \lambda \lambda \alpha$

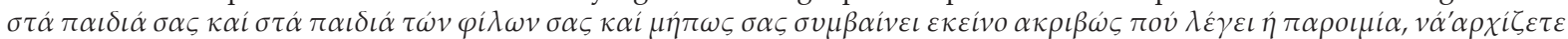

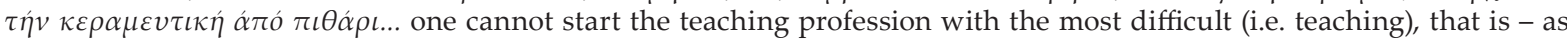
the well-known proverb says - a potter does not start being a potter by making a pitos (Plato, Laches, 187b, translation by E. Papuci-Władyka; cf. Ziomecki 1961, 62, with further literature; Poleska 2006, 70; see also http://www.perseus.tufts.edu/hopper/ text?doc=Plat.+Lach.+187b\&fromdoc $=$ Perseus\%3Atext\%3A1999.01.0175 [4. 10. 2021]).

2 On the other hand, fully wheel-made storage vessels appear at the settlements situated on the San River (Madyda-Legutko 2011, fig. 2: 11; 4: 1a, b).
} 


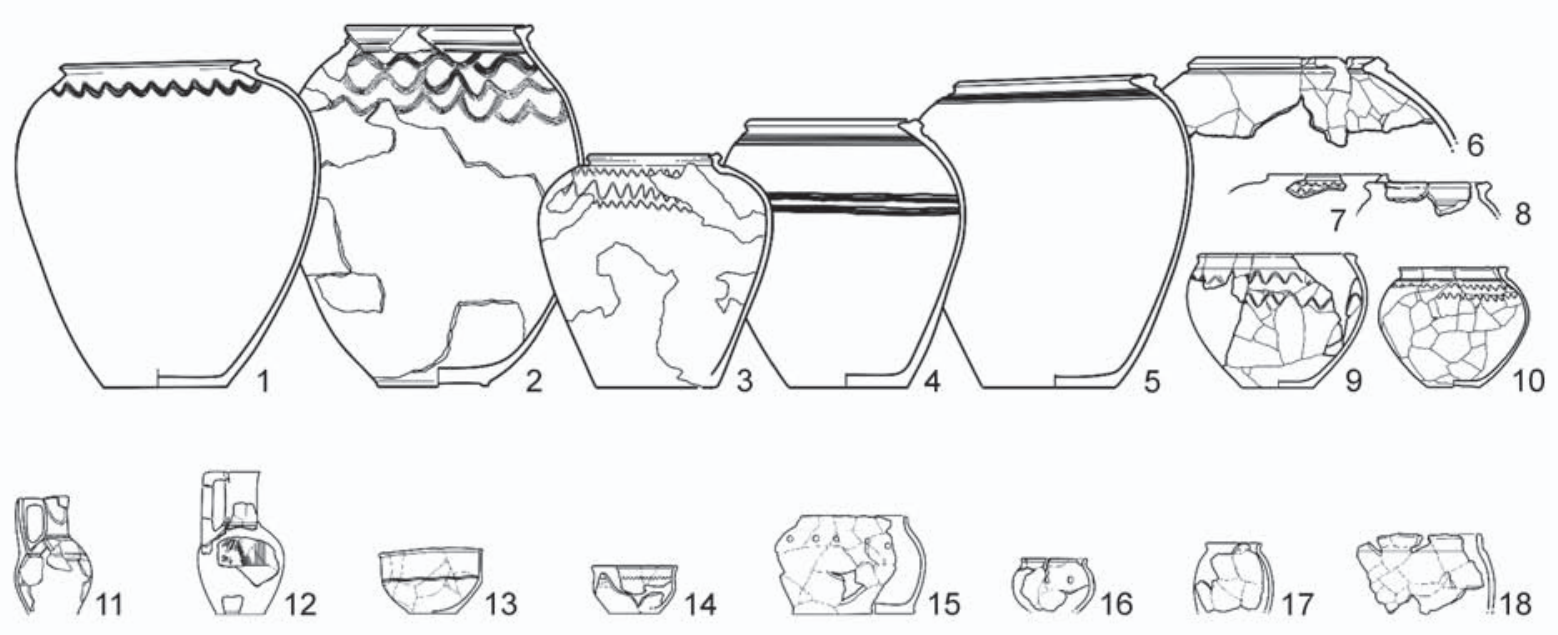

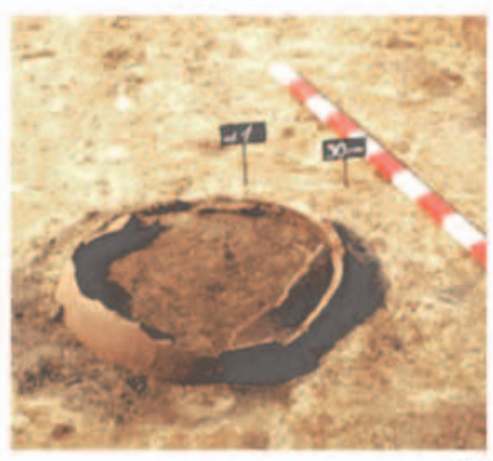

19

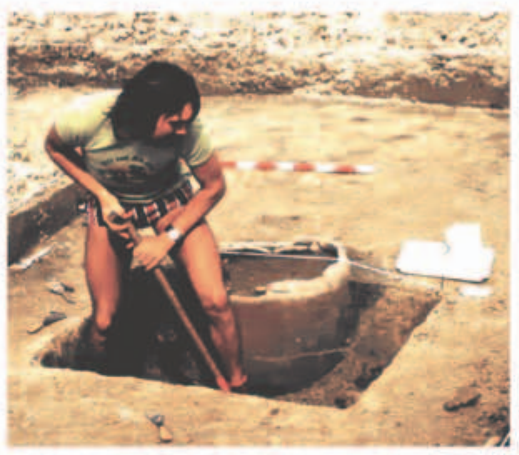

20

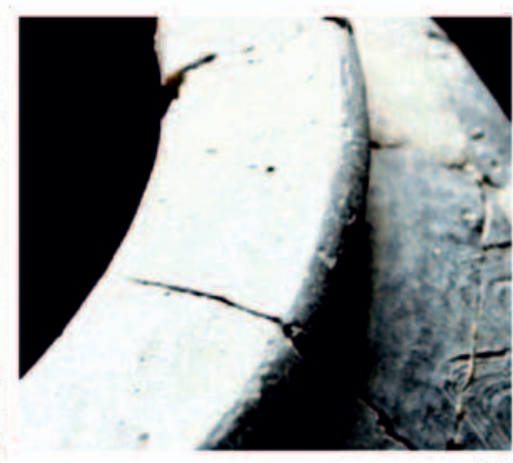

21
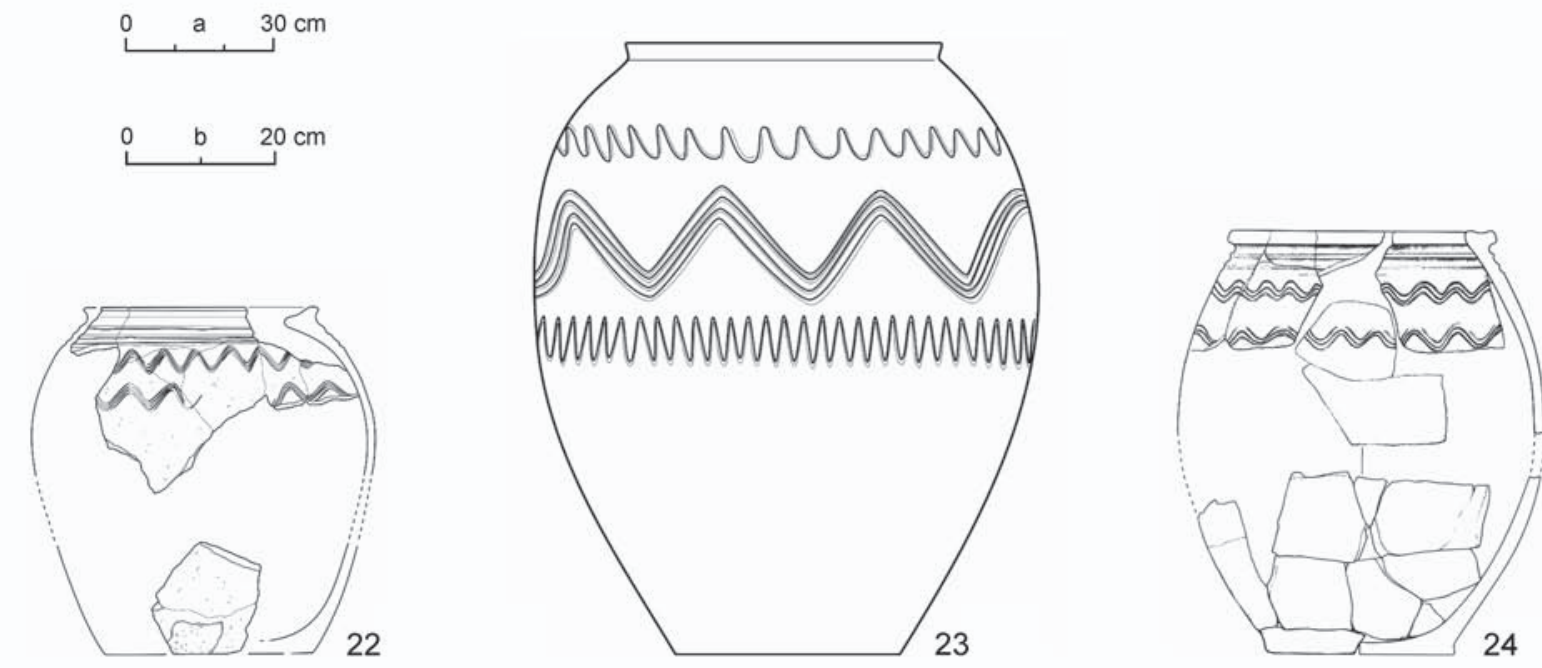

Fig. 1. Krausengefäße type storage vessels. 1-18 - Rytro, Nowy Sącz distr., site A (Madyda-Legutko/Tunia 1993, 36, 37; drawing by U. Socha); 19, 20 - Moszczenica Wyżna, Nowy Sącz distr., site C, exploration of storage vessel dug into the ground (photo by K. Tunia); 21 - Rytro, Nowy Sącz distr., site A, feature no. 5/81, broad, flange-like rim of storage vessel no. 1 (Madyda-Legutko/Tunia 1993, pl. XXI: a; photo M. Grygiel); 22 - Podegrodzie, Nowy Sącz distr., Archaeological Museum in Kraków collection (drawing by U. Potyrała); 23 - Vyšný Kubín, Dolný Kubín distr., Ostrá skala Mt. (Pieta 1991, fig. 5: 10); 24 - Hrdoš Mt. at the border between Žaškov, Dolný Kubín distr. and Komjatná, Ružomberok distr. (Lofajová Danielovál Furman 2019, pl. 1: 1). Scale: a -1-18; b-22-24. 
fig. 13; Madyda-Legutko 2011, fig. 6: 1a-c). A large, flat stone lay between the rim sherds; it may have served as a lid. The vessel contained caryopses of various cereals (Lityńska 1985, 158, tab. 3). According to M. Lityńska, the data was insufficient to reconstruct the structure of crops. However, it cannot be excluded that the presence of various caryopses in the vessel may indicate shared storage of different cereals or that different grain species were sown within one field (Tunia 2004, 346). The hut next to which the vessel was dug, contained upper parts of four storage vessels and base sherds of seven more (Madyda-Legutko/Tunia 1978, 125, fig. 12: a-c).

At the settlement at Rytro, Nowy Sącz district, site A (485 $\mathrm{m}$ a.s.1.), fragments of several storage vessels were found by the northern inner wall of a hut (feature no. 5/81), in a shallow, longitudinal depression (Madyda-Legutko/Tunia 1993, 36, 37). Together with other vessel fragments, they formed a distinct pottery cluster, from which five whole vessels of different dimensions (Fig. 1: 1-5) and large parts of three other vessels (Fig. 1: 6-8) were reconstructed. The cluster also included kitchenand tableware, represented by hand-made pots (Fig. 1: 15-18), wheel-made bowls (Fig. 1: 13, 14) and two deep 'bowls' with flange-shaped rims made of the same clay as the one used to manufacture the large storage vessels (Fig. 1: 9, 10). Jugs with the handle bent at a right angle and with a groove inside (Fig. 1: 11, 12) were found at both ends of the cluster. This arrangement of vessels, observed during the excavations, corresponds to their original placement in the hut. Apart from the cluster described above, the feature also contained numerous sherds from various vessels, including hand-made pots (Madyda-Legutko/Tunia 1993, 28). It should be noted that fragments of storage vessels were also found in the other sixteen features discovered at the Rytro settlement (Madyda-Legutkol Tunia 1993, 53).

At the settlement at Piwniczna, Nowy Sącz district, site A (602 $\mathrm{m}$ a.s.1.), the upper part of a storage vessel was found in the centre of the remains of a large hut (feature no. 3); its fill also contained numerous fragments of other vessels of this type (Madyda-Legutko/Tunia 1993, fig. 4: a-e). It has been suggested that there were at least nine storage vessels there (Madyda-Legutko/Tunia 1980, 147, 148; 1993, 61).

Large numbers of storage vessels have been observed not only at the settlements established in the Beskid Sacdecki Mts but also at the settlements existing in the intra-mountainous Sacz Basin. Unfortunately, due to the rescue nature of the excavations carried out there, we do not have detailed information regarding the deposition of vessels. Two clusters of storage vessel sherds were discovered at the settlement at Nowy SaczBiegonice, site 20 (305 m a.s.l.); the vessels were most probably embedded in the ground (Cabalskal Madyda-Legutko/Tunia 1990, 165, fig. 12: a, b; 23: f, g). Additionally, the number of other storage vessels from said settlement can be estimated at least five specimens (Cabalska/Madyda-Legutko/Tunia 1990, fig. 17: k; 20: d-f; 21: c; 22: c-e; 23: e). At the settlement at Podegrodzie, Nowy Sącz district $(314 \mathrm{~m}$ a.s.l.), excavated in 1953 (Madyda-Legutko 1995, no. 553; 1996, 10), the upper parts of at least three storage vessels were discovered in a settlement pit (Fig. 1: 22). There was also a jug there (Madyda-Legutkol Tunia 2020, fig. 7: 5). Fragments of a storage vessel were also discovered at the multicultural settlement at Stary Sącz, site 1 - Na Lipiu (320 m a.s.l.; Jodłowski 1988, 11-13, fig. 3).

At other settlements excavated in the Polish Carpathian zone, storage vessels occur - as mentioned before - in large numbers. Intentional digging of storage vessels into the ground has also been confirmed (Madyda-Legutko/Tunia 2020, 292). Such a practice is also known from the areas north of the Carpathians, from the territory of the Przeworsk culture (Kaczanowski/Madyda-Legutko 1988, 263; Rodzińska-Nowak 2012, 134, 135; Stasiak-Cyran 2016, 71). Of note is the distribution of storage vessels at the settlement at Przywóz, Wielun district, on the Warta River, which resembles the one from Moszczenica Wyżna, site C. A large storage vessel was embedded in the ground outside a residential building, while in the centre of the building and closer to the western wall, there were fragments of two other such vessels (Jadczyk 1971, 176, fig. 4; Jadczykowa 1973, 131, 148, fig. 5; pl. II: 8, 9). The digging of storage vessels into the ground is a manifestation not only of an adaptation of a practice originating in the Mediterranean civilisation (Fig. 2: 3), but also of the manner in which they were used.

Outside the Beskid Sądecki Mts, storage vessels in the Polish Carpathians are found not only in residential dwellings but also in various types of pits. A trapezoidal pit (feature no. 4/65) at the settlement at Świerchowa, Jasło district, site 1, contained fragments of at least four storage vessels and other pottery (Szałapata 1966, 35, fig. 2; 3: a, c; 4: b, e). It should be taken into consideration, however, that the fragments of storage vessels found in some pits at settlements (e.g. Podegrodzie, Świerchowa) may have been discarded as waste. At the settlement at Lesko, Lesko district, on the San River, in pit no. 14 (homestead II), interpreted by the researcher as an in-ground storage, there were supposed to be fragments of at least three storage vessels and numerous other potsherds (Barłowska 1984, 58-60, pl. I: 1, 3, 5, 

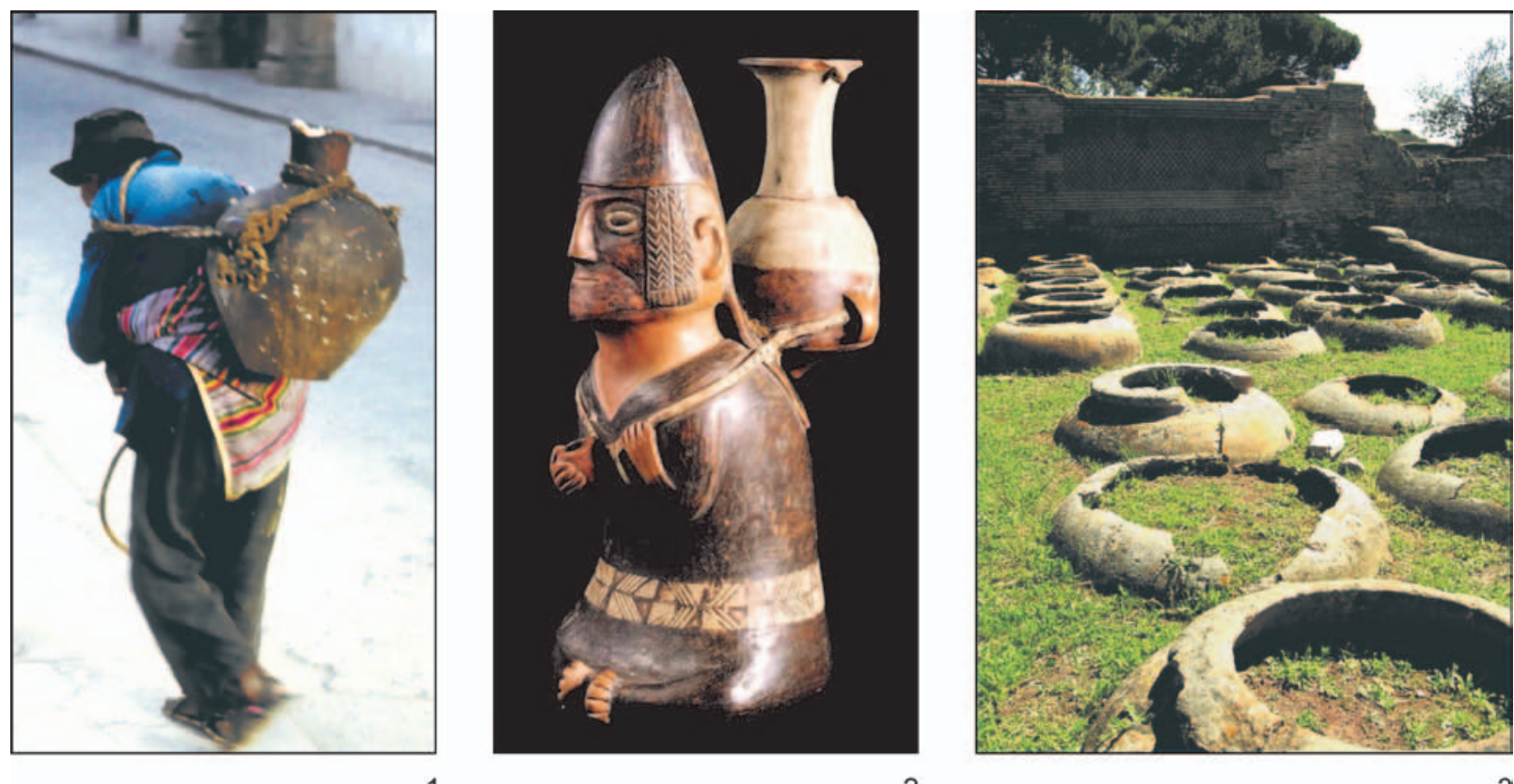

1

2

Fig. 2. Ethnological and historical analogies to storage vessels. 1 - porter carrying vessel with a liquid, Ayacucho, Peru 1978 (photo by K. Tunia); 2 - porter carrying an aryballos, Pachacamac, Peru, Inca culture, around 1500, Ethnologisches Museum der Staatlichen Museen zu Berlin (photo by D. Graf); 3 - dolia dug into the ground, Ostia Antica, Italy (photo by J. Zagórska-Telega).

7, 8). The pit also contained burnt remains of various species of cereals and other crops (Barłowska 1984, 80-82, 89; Lityńska-Zajac 2004, 365). Emmer wheat and spelt have been preserved in the form of naked caryopses and loose fragments of chaff, which gives reason to assume that they were stored after threshing. Hulless oat caryopses, which may belong to the cultivated form of Avena sativa or the wild form of A. fatua (Bartowska 1984, 80-82, 89; Lityńska-Zajac 2004, 373), as well as barley (Hordeum vulgare $L$.) and rye (Secale cereale $L$.) were also present. The Lesko researcher believes that, between the three homesteads (I, II, III), the population living there used at least 20 storage vessels during the time the settlement was occupied (Bartowska 1984, 89). It should be stressed, however, that, despite the numerous finds of storage vessels both in the Polish Carpathians and in the area of the Przeworsk culture, the vessels containing cereal remains are rare (cf. Dobrzańska 1981, 265).

It is also worth mentioning that numerous storage vessels have been found in the remains of settlements in Slovakia, within the North Carpathian group. In Orava, in the village of Vyšný Kubín, Dolný Kubín district, at the Ostrá skala site $(812 \mathrm{~m}$ a.s.l.), in a small test unit E/75, three storage vessels were discovered in a space of $3 \times$
5 m (Čaplovič 1976, 81; 1987, fig. 83; Pieta 1991, fig. 5: 10). One of them is the largest example of such pottery heretofore known from the whole range of the North Carpathian group. It is $89 \mathrm{~cm}$ high (Fig. 1: 23). Two large storage vessels were discovered on the border between Orava and Liptov, on the mountain of Hrdoš (950 m a.s.l.) in the Velká Fatra Mts (Fig. 1: 24; Lofajová Danielová/Furman 2019, pl. 1: 1, 5). Numerous remains of storage vessels have been encountered at the sites of the North Carpathian group located at similarly high altitudes in Liptov. They are known from Liptovský Ján, Liptovský Mikuláš district, site Hrádok (876 m a.s.l.; Pieta 1992, 86, 87) and Turík, Ružomberok district, site Hradište (947 m a.s.l.; Benediková/Pieta 2018, 177; Pieta 1991, fig. 5: 11). Numerous examples of storage vessels are also known from the settlements of the North Carpathian group in Spiš (Giertlová-Kučerová/Soják 2005, 122, fig. 8: 7, 8; 9: 1, 2; 10: 3, 4; 14: 2, 5-7; Pieta 2003, 156-158, fig. 6: 22, 24).

In the archaeological literature, it has been assumed that storage vessels served as grain containers while also noting that, due to their varied size, they may have had other functions (Gajewski 1959, 135; Pazda 1980, 202; Rodzińska-Nowak 2012, 135; Wielowiejski 1960, 117, 152). However, it should be

${ }^{3} \mathrm{http}: / /$ doradztworolnicze.com.pl/magazynowy-odwieczny-problem [21. 1. 2021] 


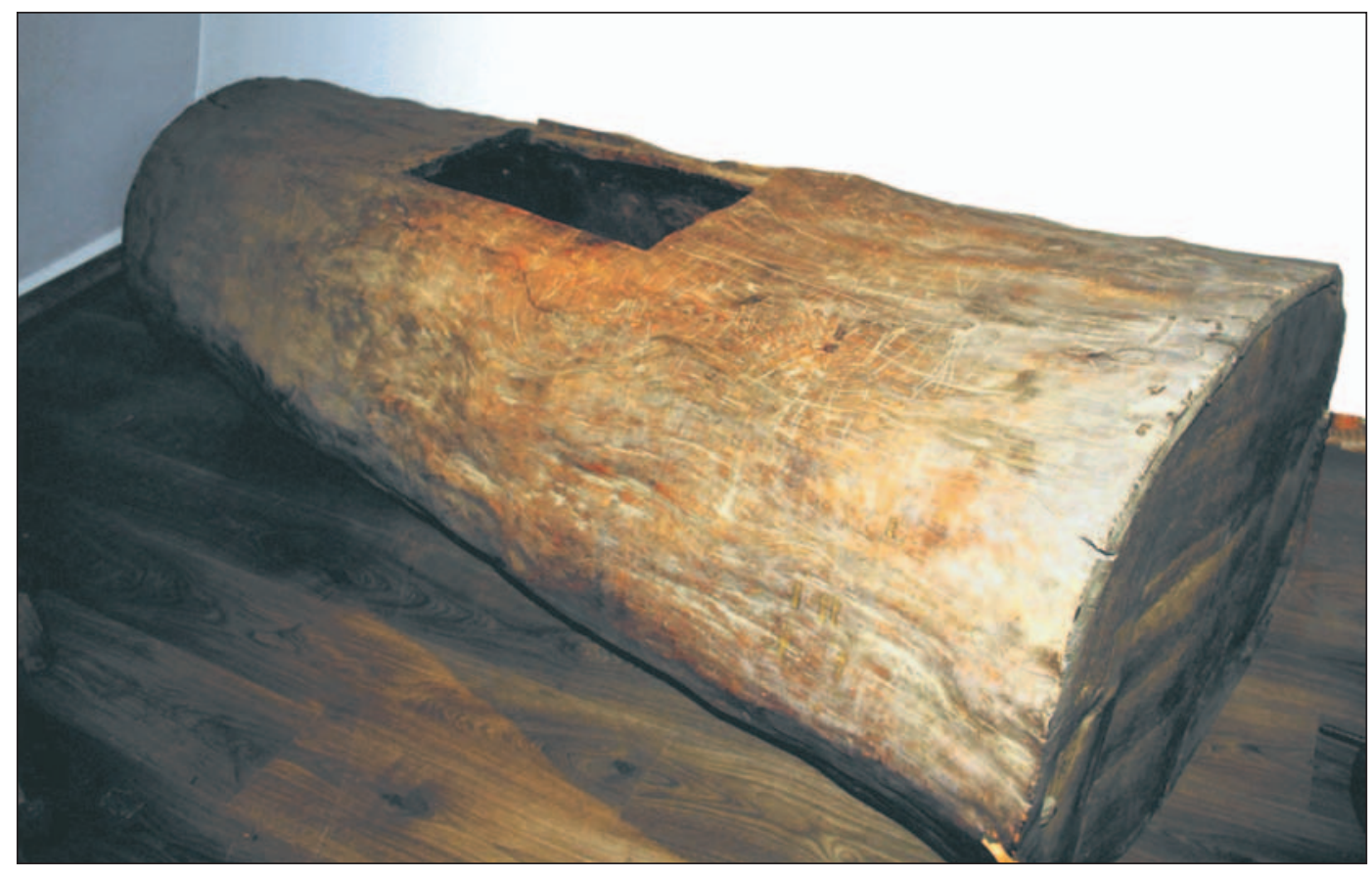

Fig. 3. Ethnological and historical storage vessel. Wooden 'container' for a grain, Tylicz, Nowy Sącz distr., product of Carpathian Lemkos, the turn of the $19^{\text {th }}$ and $20^{\text {th }}$ C., Museum in Tylicz collection (photo by J. Kieblesz).

emphasised that grain stored in living quarters for a long time would spoil due to high humidity and temperature. Longer storage of grain without loss of quality is possible at a temperature below $16^{\circ} \mathrm{C}$ and at a humidity of at most $12 \% .{ }^{3}$ Various ground granaries as well as pits dug into the ground and properly secured against birds, rodents and postharvest pests were definitely better suited for such storage. Some aspects related to this issue have been mentioned before (cf. Bednarczyk 1988, 172, 173; Coles 1977, 44-53; Rodzińska-Nowak 2012, 133, 134; Skowron 2014, 72-77). Large storage vessels discovered in the remains of houses must have served a different purpose. It has also been considered in the literature that they may have been used to make pickles (Gajewski 1959, 135; Pazda 1980, 202; Rodzińska-Nowak 2012, 135; 2017, 655) or to store food preserved with salt, as it was observed at Carnuntum (Grünewald 1979, 56).

It seems to us, however, that the storage vessels kept inside houses were local 'pantries', a place for storing various agricultural and gathered produce and its products, which were intended for direct consumption. They may also have contained processed food obtained through husbandry or hunting. Perhaps some of them were used to store relatively small quantities of grain for immediate everyday needs. It cannot be excluded that they also held drinking water.
The set of storage vessels was probably complemented by containers made of organic materials, such as baskets or containers made of wood, which have not been preserved. Wooden 'containers' hollowed out of tree trunks, known also from the Carpathians, may serve as an interesting ethnological example of objects intended for long-term storage of cereals (Fig. 3). On the other hand, vessels dug into the ground outside houses could have served as local reservoirs of water for consumption or pottery manufacture, possibly carried from streams or springs in other, slightly smaller, 'storage' vessels. Tight cover would make such a transport easier. Ethnological documentation from a remote mountainous region in the Andes, where large ceramic vessels were used for foot transport of liquids, may act as a proof that this is indeed possible. Such containers even of considerable size and weight, carried on the back, successfully fulfilled their role (Fig. 2: 1, 2).

It is also worth drawing attention to the secondary uses of the type of pottery under discussion; a well-preserved hearth made from sherds of large vessels discovered in the village of Siemonia, Będzin district (Krauss 1955, 104) may serve as an example. Likewise, an ad hoc adaptation of large potsherds within a homestead, e.g. as pot lids or drinking troughs for animals, cannot be excluded.

Due to their size and weight, storage vessels were most probably made at the site of their later 
use. This is evidenced by the fragments of broken specimens in the backfills of already-out-of-use pottery kilns at some settlements. Such a situation was recorded in the Carpathian Mountains in Sanok, Sanok district, at site 59-60 (Bulas et al. 2019, 72, fig. 12: 3-7) and site 54 (Madyda-Legutko 2011, fig. 3: 10; 4: 1-7; Madyda-Legutko/PohorskaKleja/Rodzińska-Nowak 2008, 10-15, fig. 3: 1; 4:1-7, 10-16, 18), and at Lipnica Dolna, Jasło district, site 8 (Kłosowicz/Leszczyński 2017, pl. III: 1-3, 5-8; IV: 1, 2, 4, 9-11; V: 1, 3-7; VI: 6, 8; VII: 1, 2, 9-10; VIII: 7). It is worth it here to draw attention to the research on the identification of the raw materials used to make the storage vessels discovered at the settlement of the Przeworsk culture at Kolonia Nieszawa, Opole Lubelskie district. Considering the chemical composition and thermal behaviour of the pottery samples and their comparison with local clays, it has been shown that two samples (vessels), may be 'imports' from outside the re- gion (Daszkiewicz/Schneider/Bobryk 2016, 239-241, tab. 2). Assuming the results are correct, they may suggest that the vessels were not made on site but transported to the place of use. Based on their technological and stylistic similarity, it has also been suggested in the literature that the storage vessels from Giecz, Środa Wielkopolska district (northern Greater Poland), were made in Silesia and shipped to their users over a considerable distance (Żychliński 1999). The suggestion that such vessels were used as containers in trade, especially when using waterways, is also worth mentioning here (Pazda 1980, 202).

These and other specialist analyses of the Krausengefäße type storage vessels from the Late Roman Period and the beginning of the Migration Period may validate a number of statements concerning their use and manufacture mentioned in the article, which are merely suggestions at the current stage of research.

\section{BIBLIOGR APHY}

Barłowska 1984 - A. Barłowska: Osada z późnego okresu wpływów rzymskich w Lesku, woj. Krosno. Materiały i Sprawozdania Rzeszowskiego Ośrodka Archeologicznego za lata 1976-1979, 1984, 51-101.

Bednarczyk 1988 - J. Bednarczyk: Der Ausgrabungen eines Kultplatzes und einer Siedlung der Przeworsk-Kultur in Inowrocław, Kujawien. Offa 45, 1988, 167-180.

Benediková/Pieta 2018 - L. Benediková/K. Pieta: Využitie krajiny stredného Liptova v praveku a včasnej dobe dejinnej. Študijné zvesti Aú SAV 63, 2018, 147-196.

Błażejewski 2008 - A. Błażejewski (red.): Ceramika warsztatowa w środkowoeuropejskim Barbaricum. Wrocław 2008.

Boege 1937 - W. Boege: Ein Beitrag um Formenkreis der wandalischen Irdenware aus Völkerwanderungszeit. Altschlesien 7, 1937, 44-59.

Bohr 2008 - M. Bohr: Zur sogenannten keramischen Gruppe von Boege. In: Błażejewski 2008, 287-292.

Bulas et al. 2019 - J. Bulas/M. Mazurek/M. Okońska/W. Pordyło: Wielokulturowe stanowisko 59-60 w Sanoku w świetle badań wykopaliskowych z lat 2017-2018. Raport 14, 2019, 55-81.

Cabalska/Madyda-Legutko/Tunia 1990 - M. Cabalska/R. Madyda-Legutko/K. Tunia: Wyniki badań stanowiska z epoki brązu, początków epoki żelaza i z późnego okresu rzymskiego w Nowym Sączu-Biegonicach. Acta Archaeologica Carpathica 29, 1990, 163-214.

Čaplovič 1976 - P. Čaplovič: Sídlisko z doby rímskej a slovanskej na Ostrej skale nad Vyšným Kubínom. AVANS 1975, 1976, 78-82.

Čaplovič 1987 - P. Čaplovič: Orava v praveku, vo včasnej dobe dejinnej a na začiatku stredoveku. Martin 1987.

Coles 1977 - J. Coles: Archeologia doświadczalna. Warszawa 1977.

Daszkiewicz/Schneider/Bobryk 2016 - M. Daszkiewicz/ G. Schneider/E. Bobryk: Nieszawa Kolonia, ceramika z okresu rzymskiego - technologia i pochodzenie w świetle badań laboratoryjnych. In: M. Stasiak-Cyran (red.): Nieszawa Kolonia stanowisko 5, pow. Opole Lubelskie. Interdyscyplinarna monografia osady z okresu rzymskiego. Lublin 2016, 225-243.

Dobrzańska 1981 - H. Dobrzańska: Z zagadnień gospodarki ludności kultury przeworskiej w okresie rzymskim na obszarze Małopolski. Acta Archaeologica Carpathica 21, 1981, 259-271.

Dobrzańska 1990 - H. Dobrzańska: Osada z późnego okresu rzymskiego w Igołomi, woj. krakowskie. Część II. Kraków 1990.

Furger-Gunti 1979 - A. Furger-Gunti: Die Ausgrabungen im Basel Münster I. Die spätkeltische und augusteische Zeit (1. Jahrhundert v. Chr.). Untersuchungen zur spätkeltisch-frührömischen Übergangszeit in Basel. Basler Beiträge zur Ur- und Frühgeschichte. Band 6. Derendingen Solothurn 1979.

Gajewski 1959 - L. Gajewski: Badania nad organizacją produkcji pracowni garncarskich z okresu rzymskiego w Igołomi. Archeologia Polski 3, 1959, 101-158.

Giertlová-Kučerová/Soják 2005 - M. Giertlová-Kučerová/ M. Soják: Novšie nálezy severokarpatskej skupiny v povodí rieky Poprad. Študijné zvesti AÚ SAV 38, 2005, 113-136.

Godtowski 1969 - K. Godłowski: Kultura przeworska na Górnym Ślasku. Katowice 1969.

Grünewald 1979 - M. Grünewald: Die Gefäßkeramik des Legionslagers von Carnuntum (Grabungen 1968-1974). Der römische Limes in Österreich 29. Wien 1979.

Jadczyk 1971 - I. Jadczyk: Wyniki badań w Przywozie, pow. Wieluń, na stanowisku 1 i la z okresu wpływów rzymskich. Sprawozdania Archeologiczne 23, 1971, 169-180.

Jadczykowa 1973 - I. Jadczykowa: Budynki mieszkalne osady produkcyjnej w Przywozie, pow. Wieluń, część I. Prace 
i Materiaty Muzeum Archeologicznego i Etnograficznego w Eodzi. Seria Archeologiczna 20, 1973, 129-162.

Jahn 1925 - M. Jahn: Schlesien zur Völkerwanderungszeit. In: G. Kossina (Hrsg.): Bericht über die achte Tagung der Gesellschaft für deutsche Vorgeschichte. Cöthen 10.-14. Juni 1924. Mannus. Ergänzungsband 4. Leipzig 1925, 147-156.

Jodłowski 1988 - A. Jodłowski: Badania osady wielokulturowej w Starym Sączu na stanowisku 1. Badania archeologiczne prowadzone przez Muzeum Żup Krakowskich Wieliczka w latach 1986-1987. Wieliczka 1988, 5-13.

Kaczanowski/Madyda-Legutko 1988 - P. Kaczanowski/ R. Madyda-Legutko: Wyniki badań osady z okresu późnorzymskiego w Drochlinie, woj. Częstochowa, stan. 3. Sprawozdania Archeologiczne 40, 1988, 245-269.

Kłosowicz/Leszczyński 2017 - M. Kłosowicz/T. Leszczyński: Wyniki badań osady z okresu wpływów rzymskich w Lipnicy Dolnej, stan. 8, pow. jasielski. In: J. Gancarski (red.): Stan i potrzeby badań archeologicznych w Karpatach. Krosno 2017, 451-519.

Krauss 1955 - A. Krauss: Cmentarzysko rzymskie i osada odkryte w miejscowości Siemonia- Kolonia Podmłynie, pow. Będzin. Wiadomości Archeologiczne 22, 1955, 104-106.

Lamiová-Schmiedlová/Tomášová 1999 - M. Lamiová-Schmiedlová/B. Tomášová: Nálezový horizont z prelomu doby rímskej a doby stłahovania národov na viacvrstvovom sídlisku v Ostrovanoch. Slovenská archeológia 47, 1999, 75-142.

Lityńska 1985 - M. Lityńska: Szczątki roślinne z okresu wpływów rzymskich ze stanowiska A i C w Moszczenicy Wyżnej, woj. nowosądeckie. Acta Archaeologica Carpathica 24, 1985, 153-168.

Lityńska-Zająć 2004 - M. Lityńska-Zając: Szczątki roślinne z okresu rzymskiego ze stanowisk archeologicznych w polskiej części Karpat. In: J. Gancarski (red.): Okres lateński i rzymski w Karpatach polskich. Krosno 2004, 363-387.

Lofajová Danielová/Furman 2019 - B. Lofajová Danielová/ M. Furman: Hrdoš - nová archeologická lokalita severokarpatskej skupiny na pomedzí Oravy a Liptova. Zborník Slovenského národného múzea 113. Archeológia 29, 2019, 269-281.

Machajewski/Pietrzak 2008-H. Machajewski/R. Pietrzak: Ze studiów nad ceramiką naczyniową kultury przeworskiej z późnego okresu rzymskiego i wczesnej fazy okresu wędrówek ludów w Wielkopolsce. In: Błażejewski 2008, 225-251.

Madyda-Legutko 1995 - R. Madyda-Legutko: Zróżnicowanie kulturowe polskiej strefy beskidzkiej w okresie lateńskim i rzymskim. Katalog stanowisk. Uniwersytet Jagielloński. Rozprawy Habilitacyjne nr 304/2. Kraków 1995.

Madyda-Legutko 1996 - R. Madyda-Legutko: Zróżnicowanie kulturowe polskiej strefy beskidzkiej w okresie lateńskim i rzymskim. Uniwersytet Jagielloński. Rozprawy habilitacyjne nr 304/1. Kraków 1996.

Madyda-Legutko 2011 - R. Madyda-Legutko: Drehscheibenkeramik aus dem Gebiet der polnischen Karpaten zur regionalen Differenzierung. In: J. Bemmann/ M. Hegewisch/ M. Meyer/M. Schmauder (Hrsg.): Drehscheibentöpferei im Barbaricum. Technologietransfer und Professionalisierung eines Handwerks am Rande des Römischen Imperiums. Bonner Beiträge zur Vor- und Frühgeschichtlichen Archäologie 13. Bonn 2011, 295-306.
Madyda-Legutko/Pohorska-Kleja/Rodzińska-Nowak 2008 R. Madyda-Legutko/E. Pohorska-Kleja/J. Rodzińska-Nowak: Ceramika z warsztatu garncarskiego z Sanoka, stan. 54, na tle materiałów ceramicznych z terenu górnego dorzecza Sanu. Próba interpretacji. In: Błażejewski 2008, 9-23.

Madyda-Legutko/Tunia 1978 - R. Madyda-Legutko/K. Tunia: Wyniki badań stanowisk okresu rzymskiego w Moszczenicy Wyżnej, woj. Nowy Sącz. Acta Archaeologica Carpathica 18, 1978, 113-149.

Madyda-Legutko/Tunia 1980 - R. Madyda-Legutko/K. Tunia: Wyniki badań stanowiska z okresu rzymskiego w Piwnicznej, woj. Nowy Sącz. Acta Archaeologica Carpathica 20, 1980, 143-152.

Madyda-Legutko/Tunia 1993 - R. Madyda-Legutko/K. Tunia: Rytro. Karpacka osada z okresu wędrówek ludów. Zeszyty Naukowe Uniwersytetu Jagiellońskiego 1118. Prace Archeologiczne 57. Kraków 1993.

Madyda-Legutko/Tunia 2020 - R. Madyda-Legutko/K. Tunia: Decline of antiquity and the beginning of a new era in the Polish Carpathians. Študijné zvesti AÚ SAV 67, 2020, 285-308.

DOI: https://doi.org/10.31577/szausav.2020.67.14

Marchelak 2010 - I. Marchelak: Materiały z osady z wczesnego okresu wędrówek ludów w Bizorendzie, stanowisko 12, gm. Sobków, woj. świętokrzyskie. In: H. Machajewski/B. Jurkiewicz (red.): Ceramika rzemieślnicza jako źródło do badań nad zróżnicowaniem garncarstwa kultury przeworskiej. Pułtusk 2010, 101-161.

Pazda 1980 - S. Pazda: Studia nad rozwojem i zróżnicowaniem lokalnym kultury przeworskiej na Dolnym Śląsu. Acta Universitatis Wratislaviensis 443. Studia Archeologiczne 10. Wrocław 1980.

Peña 2011 - J. T. Peña: Roman Pottery in the Archaeological Record. Cambridge 2011.

Pieta 1991 - K. Pieta: The North Carpathians at the beginning of the Migration Period. Antiquity 65, 1991, 376-387. DOI: https://doi.org/10.1017/S0003598X00079886

Pieta 1992 - K. Pieta: Nálezy zo začiatku doby stahovania národov v Liptovskom Jáne. AVANS 1990, 1992, 86, 87.

Pieta 2003 - K. Pieta: Spiš vo včasnej dobe dejinnej. In: R. Gładkiewicz/M. Homza (red.): Terra Scepusiensis. Stan badań nad dziejami Spiszu. Levoča - Wrocław 2003, 149-159.

Poleska 2006 - P. Poleska: Celtycki mikroregion osadniczy $w$ rejonie podkrakowskim. Biblioteka Muzeum Archeologicznego w Krakowie 2. Kraków 2006.

von Richtchofen 1928 - B. von Richtchofen: Germanische Krausengefäße des 4. Jahrhunderts n. Chr. aus der Provinz Oberschlesien und ihre weitere Verbreitung. In: Festgabe für den 70jährigen Gustaf Kossinna von Freunden und Schülern. Mannus. Ergänzungsband 6. Leipzig 1928, 73-95.

Rodzińska-Nowak 2006 - J. Rodzińska-Nowak: Jakuszowice stanowisko 2. Ceramika z osady kultury przeworskiej z młodszego i późnego okresu wpływów rzymskich i wczesnej fazy okresu wędrówek ludów. Prace Archeologiczne 61. Kraków 2006

Rodzińska-Nowak 2012 - J. Rodzińska-Nowak: Gospodarka żywnościowa ludności kultury przeworskiej. Kraków 2012.

Rodzińska-Nowak 2017 - J. Rodzińska-Nowak: Niech skiśnie! O niektórych sposobach konserwowania i przetwarzania pożywienia pochodzenia roślinnego w pradziejach. In: J. Andrzejewski/C. von Carnap-Bornheim/ 
A. Cieśliński/B. Kontny (red.): Orbis Barbarorum. Studia ad archaeologiam Germanorum et Baltorum temporibus Imperii Romani pertinentia Adalberto Nowakowski dedicata. Monumenta Archaeologica Barbarica. Series Gemina 6. Warszawa - Schleswig 2017, 653-657.

Skowron 2014 -J. Skowron: Osada w działaniu. Osady ludności kultury przeworskiej w Polsce Środkowej od młodszego okresu przedrzymskiego do okresu wędrówek ludów. Biblioteka Wielkopolskich Sprawozdań Archeologicznych 7. Poznań 2014.

Stasiak-Cyran 2016 - M. Stasiak-Cyran: Charakterystyka osady w Nieszawie Kolonii w świetle analizy źródeł archeologicznych i badań interdyscyplinarnych. In: M. Stasiak-Cyran (red.): Nieszawa Kolonia stanowisko 5, pow. Opole Lubelskie. Interdyscyplinarna monografia osady z okresu rzymskiego. Lublin 2016, 10-210.

Szałapata 1966 - A. Szałapata: Badania archeologiczne w Świerchowej, pow. Jasło. Materiały i Sprawozdania Rzeszowskiego Ośrodka Archeologicznego za rok 1965, 1966, 35-44.

Śmiszko 1939/1948 - M. Śmiszko: Duże naczynia baniaste okresu rzymskiego w Małopolsce Wschodniej. Wiadomości Archeologiczne 16, 1939/1948, 211-233.

Tunia 2004 - K. Tunia: Środowiskowe uwarunkowania gospodarki rolniczo-hodowlanej na terenach górskich w czasach prahistorycznych. Casus zachodniokarpackiego osadnictwa późnorzymskiego. In: J. Gancarski (red.): Okres lateński i rzymski w Karpatach polskich. Krosno 2004, 329-356.

Manuscript accepted 27. 5. 2021

Translated by Kinga Brzezińska

prof. dr hab. Renata Madyda-Legutko

Uniwersytet Jagielloński

Instytut Archeologii

ul. Gołębia 11

PL - 31-007 Kraków

rmlegutko@o2.pl
Vakulenko 2010 - L. V. Vakulenko: Ukraïns'ki Karpaty u pizn'oryms'kyj čas (etnokul'turni ta socjal'no-ekonomični procesy). Kyïv 2010.

Wielowiejski 1960 - J. Wielowiejski: Przemiany gospodarczo-społeczne u ludności potudniowej Polski wokresie późnolateńskim i rzymskim. Materiały Starożytne 6. Warszawa 1960.

Wilk 2005 - M. Wilk: Późnorzymskie naczynia zasobowe (w typie Krausengefäße) na obszarze południowo-wschodniej Polski. Materiaty i Sprawozdania Rzeszowskiego Ośrodka Archeologicznego 26, 2005, 305-372.

Woźniak 2000 - Z. Woźniak: Lateńskie dolia z Krakowa-Mogiły. In: R. Madyda-Legutko/T. Bochnak (red.): SVPERIORES BARBARI. Księga ku czci Profesora Kazimierza Godłowskiego. Kraków 2000, 301-309.

Ziomecki 1961 - J. Ziomecki: Techniki ceramiczne w starożytnej Grecji. Archeologia. Rocznik Instytutu Historii Kultury Materialnej Polskiej Akademii Nauk 12, 1961, $48-74$.

Żychliński 1999 - D. Żychliński: Szerokokołnierzowe naczynia zasobowe (typu Krausengefässe) z Giecza w Wielkopolsce Północnej. In: A. Kokowski (red.): Kultura Przeworska 4. Lublin 1999, 193-199.

Żychliński 2008 - D. Żychliński: Ceramika naczyniowa z okresu wędrówek ludów z osady ludności kultury przeworskiej w Gieczu, pow. Środa Wielkopolska, stanowisko 21-22. In: J. Skowron/M. Olędzki (red.): Kultura Przeworska. Odkrycia-interpretacje-hipotezy 2. Łódź 2008, 383-452.

dr Krzysztof Tunia

Polska Akademia Nauk

Instytut Archeologii i Etnologii

ul. Sławkowska 17

PL - 31-016 Kraków

ktunia@gmail.com 